\title{
Investment Appraisal At Imperfect Capital Markets
}

Peter Schuster, (E-mail: Schuster@Fh-Schmalkalden.de), Schmalkalden University of Applied Sciences, Germany

\begin{abstract}
Investment decisions are of vital importance to all companies. Thus, effective appraisal methods are most important tools to support the decision-making. Among the most popular methods are the Net Present Value Method, the Internal Rate of Return Method and the Annuity Method, which explicitly consider the time value of money and can be characterized by the assumption of a uniform rate and are connected with the assumption of a perfect capital market.

Aiming at a decision-making process closer to real business life we describe an investment appraisal method that assumes different credit and debtor interest rates, i.e., that is usable in imperfect capital markets. We exemplify investment appraisal in this market form with a method which visualizes any financial implications in an environment with a high number of different credit and debt interest rates, borrowing lines and other restrictions. The usage of this method is shown at examples and the appraisal of single investment projects and the comparison of mutually exclusive projects are described.
\end{abstract}

\section{INTRODUCTION}

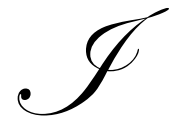

nvestment decisions are of vital importance to all companies and effective appraisal methods are most valuable tools to support the decision-making process. Among the most popular methods are the Net Present Value (NPV) Method, the Internal Rate of Return (IRR) method and the Annuity Method; they explicitly consider the time value of money and can be characterized by the assumption of a uniform rate, e.g. any future cash inflow or cash outflow can be discounted to the present point in time by the use of the same periodical discount (interest) rate. This implies the assumption that all future investments (financial investments due to cash inflow surpluses and investments to balance up the different capital tie-ups) will yield at the relevant market discount rate and, therefore, this uniform rate is one of most crucial input data of the decision process. It is connected with the assumption of a perfect capital market.

Aiming at a decision-making process closer to real business life we describe investment appraisal methods that assume different credit and debt interest rates, and select the Visualization of Financial Implications (VoFI) method (see GÖTZE, NORTHCOTT, SCHUSTER 2007 for a detailed description, comparison and model assessment of different investment appraisal methods and models) which displays financial implications in an environment with a high number of different credit and debt interest rates, borrowing lines and other financial restrictions.

Showing the method's use at a simplified example we characterize investment projects in the form of a cash flow profile that is calculated into a target measure and therefore can be assessed and compared between different, mutually exclusive projects.

\section{THE VISUALIZATION OF FINANCIAL IMPLICATIONS (VOFI) METHOD}

The method's main feature is a comprehensive financial plan that can be pictured in form of a table. It considers all cash flows and their economic consequences. Specifically, the VoFI plan considers all financial decisions concerning an investment project, e.g.: 
- $\quad$ the amounts and proportions of equity and debt capital

- $\quad$ the amounts and timing of debt redemption from cash inflows

- $\quad$ the alternate yield on the initial equity (i.e. the opportunity income value)

- $\quad$ and the existence of different forms of loans, with differing payback and interest conditions.

The VoFI method explicitly analyses both the cash flow profile of an investment project itself (the so-called original cash flows) and the cash flows from the project's financial investments (the derivative cash flows). Assumptions about payback structures, financial investment opportunities, and balancing differences in capital tie-ups, that are only implicit in other models, such as NPV and IRR, are made explicit in the VoFI method, and different assumptions can be applied to different financial arrangements when there are different forms of loans or financial investments.

The target measures for the VoFI method can be compound values, initial values, intermediate values, withdrawals or specific profitability levels. Compound values are considered here, primarily because of their clarity. They represent the balance of all financial accounts (including the loans) at the end of the economic life of an investment project and are discernible directly from the comprehensive financial plans.

The key idea is to determine profitabilities of investment projects: its absolute profitability (e.g. making this investment is better than failing to make it) and its relative profitability (investing in project $\mathrm{A}$ is better than investing in project $\mathrm{B}$ when $\mathrm{A}$ and $\mathrm{B}$ are mutually exclusive). The absolute profitability is achieved when the project's compound value exceeds the opportunity income value at the end of its economic life that can be achieved with the equity capital at disposal when not investing in the analyzed project. An investment project is relatively profitable if its compound value exceeds the compound values of alternative projects (at the same point in time - as shown in the above example).

Standardized tables can be utilized to reproduce comprehensive financial plans. Figure 1 -below- shows one example.

The first part of this table contains the original cash flows, e.g., the cash flow profile of the investment project; the project-assigned equity and its changes; the borrowing, paybacks and interest payments of four typical forms of loans; and the execution, release and interest of financial investment opportunities taken. The comprehensive financial plan always has to be balanced, i.e. the balance of all cash flows is zero in every period. In the second part of the table relevant loans and financial investments, together with their resulting balances, are recorded. At the end of the economic life, the balance obtained corresponds to the compound value of the investment project. The comprehensive financial plan and compound value calculation for an investment project require the following steps:

Step 1: at $\mathrm{t}=0$ the initial investment outlay of the investment project and the allocated (project-assigned) equity funds are recorded. In addition, the loans to be raised (or surpluses to be invested) are calculated and the status of loans and financial investments is recorded.

Step 2: for $\mathrm{t}=1$ and every subsequent period the net cash flows of the investment project are allocated. Interest payments, any borrowing or redemption of loans, and any making or discontinuation of financial investments is calculated in order to update the status of loans and financial investments.

To assess absolute profitability, compound values are calculated using the comprehensive financial plan and the allocated initial project equity is compounded with an opportunity interest rate into an opportunity income value, which is compared with the expected compound value of the project. To assess relative profitability, the inclusion of supplementary investments may be required under certain circumstances (as shown in the example). An investment project is considered absolutely profitable if its capital profitability exceeds the opportunity income value. The project with the highest capital profitability is relatively profitable. Assuming identical allocated equities and economic lives, results for both absolute and relative profitabilities are identical to those achieved by using compound value as the target measure; other target measures can be utilized, for instance periodic withdrawals (these are not taking up in this paper). 


\section{EXAMPLE}

A choice has to be made between two investment projects (example adapted from GöTzE, NORTHCOTT, SCHUSTER 2007). The following budget has been predicted:

\begin{tabular}{|l|c|c|}
\hline \multicolumn{1}{|c|}{ Data } & Investment Project I & Investment Project II \\
\hline Initial investment outlay [\$] & 10,000 & 12,000 \\
Economic life [years] & 3 & 4 \\
Net cash flows [\$] & 5,000 & 3,000 \\
in $\mathrm{t}=1$ & 5,000 & 4,000 \\
in $\mathrm{t}=2$ & 3,000 & 4,000 \\
in $\mathrm{t}=3$ & - & 6,000 \\
in $\mathrm{t}=4$ & & \\
\hline
\end{tabular}

Exercise: Assess the absolute and relative profitability of the two investment projects using the VoFI method. $\$ 5,000$ of shareholders' funds should be allocated in each case (assumed to be cash for instance). The rate of interest on the opportunity is $9 \%$, the credit interest rate for short-term $7 \%$. Project I was financed with a installment purchase loan of $\$ 4,000$ (interest of $11 \%$, annual interest payments on the balance) with a term conforming to the project's economic life, and with a current account loan (interest of 13\%, annual interest payments). In the case of project II, in addition to these forms of finance, there is a loan with payback at the end of $\$ 2,000$ (annual payments of interest, interest at $10 \%$, term of four years).

Solution: Using this data, and assuming that surpluses are used for the immediate redemption of the current account loan, the comprehensive financial plan for investment projects I+II is as follows:

Figure 1: VoFI plan for investment project I

\begin{tabular}{|c|c|c|c|c|}
\hline & $\mathbf{t}=\mathbf{0}$ & $t=1$ & $\mathbf{t}=\mathbf{2}$ & $\mathbf{t}=\mathbf{3}$ \\
\hline Cash Flow Profile & $-10,000$ & $+5,000$ & $+5,000$ & $+3,000$ \\
\hline \multicolumn{5}{|l|}{ Project-assigned Equity } \\
\hline - Withdrawal of capital & & & & \\
\hline + Contribution of capital & $+5,000$ & & & \\
\hline $\begin{array}{l}\text { Installment Purchase Loan } \\
\text { Barrowing }\end{array}$ & +4000 & & & \\
\hline $\begin{array}{l}\text { + Borrowing } \\
\text { - Redemption }\end{array}$ & $+4,000$ & -1.333 .33 & -1.333 .33 & -1.333 .33 \\
\hline - Debit Interest & & -440 & -293.33 & -146.67 \\
\hline Current Account Loan & $+1,000$ & & & \\
\hline + Borrowing & & $-1,000$ & & \\
\hline - Redemption & & -130 & & \\
\hline - Debit Interest & & & & \\
\hline \multicolumn{5}{|l|}{ Financial Reinvestment } \\
\hline $\begin{array}{l}\text { - Investment } \\
+ \text { Disinvestment }\end{array}$ & & $-2,096.67$ & $-3,520.11$ & $-1,613.16$ \\
\hline+ Credit Interest & & & +145.77 & $+393,17$ \\
\hline FINANCIAL BALANCE & 0 & 0 & 0 & 0 \\
\hline \multicolumn{5}{|c|}{ BALANCES OF LOANS AND FINANCIAL INVESTMENTS: } \\
\hline \multicolumn{5}{|l|}{ Loans } \\
\hline Installment Purchase Loan & 4,000 & $2,666.67$ & $1,333.33$ & 0 \\
\hline Loan with Final Redemption & 0 & 0 & 0 & 0 \\
\hline Annuity Loan & 0 & 0 & 0 & 0 \\
\hline Current Account Loan & 1,000 & 0 & 0 & 0 \\
\hline Financial investment & 0 & $2,096.67$ & $5,616.78$ & 7,529.94 \\
\hline NET BALANCE & $-5,000$ & -570 & $+4,283,44$ & $+7,529.94$ \\
\hline
\end{tabular}


The compound value of project I amounts to $\$ 7,529.94$. Because this exceeds the opportunity income value $\left(\$ 5,0001.09^{3}=\$ 6,475.15\right)$, the project is absolutely profitable.

The comprehensive financial plan for investment project B is shown in figure 2:

Figure 2: VoFI plan for investment project II

\begin{tabular}{|c|c|c|c|c|c|}
\hline & $t=0$ & $\mathrm{t}=1$ & $\mathrm{t}=2$ & $\mathrm{t}=3$ & $\mathrm{t}=4$ \\
\hline Cash Flow Profile & $-12,000$ & $+3,000$ & $+4,000$ & $+4,000$ & $+6,000$ \\
\hline \multicolumn{6}{|l|}{\begin{tabular}{|l|} 
Project-assigned Equity \\
\end{tabular}} \\
\hline - Withdrawal of capital & & & & & \\
\hline+ Contribution of capital & $+5,000$ & & & & \\
\hline \multicolumn{6}{|l|}{ Installment Purchase Loan } \\
\hline + Borrowing & $+4,000$ & & & & \\
\hline - Redemption & & $-1,000$ & $-1,000$ & $-1,000$ & $-1,000$ \\
\hline - Debit Interest & & -440 & -330 & -220 & -110 \\
\hline \multicolumn{6}{|l|}{ Loan with Final Redemption } \\
\hline + Borrowing & $+2,000$ & & & & \\
\hline - Redemption & & & & & $-2,000$ \\
\hline - Debit Interest & & -200 & -200 & -200 & -200 \\
\hline \multicolumn{6}{|l|}{ Current Account Loan } \\
\hline+ Borrowing & & $-1,000$ & & & \\
\hline - Redemption & & -130 & & & \\
\hline - Debit Interest & & & & & \\
\hline \multicolumn{6}{|l|}{ Financial Reinvestment } \\
\hline - Investment & & -230 & $-2,486.10$ & $-2,770.13$ & $-3,074.04$ \\
\hline + Disinvestment & & & & & \\
\hline+ Credit Interest & & & +16.10 & $+190,13$ & -384.04 \\
\hline FINANCIAL BALANCE & 0 & 0 & 0 & 0 & 0 \\
\hline \multicolumn{6}{|c|}{ BALANCES OF LOANS AND FINANCIAL INVESTMENTS: } \\
\hline \multicolumn{6}{|c|}{ Loans } \\
\hline Installment Purchase Loan & 4,000 & 3,000 & 2,000 & 1,000 & 0 \\
\hline Loan with Final Redemption & 2,000 & 2,000 & 2,000 & 2,000 & 0 \\
\hline Annuity Loan & 0 & 0 & 0 & 0 & 0 \\
\hline Current Account Loan & 1,000 & 0 & 0 & 0 & 0 \\
\hline Financial investment & 0 & 230 & $2,716.10$ & $5,486.23$ & $8,560.27$ \\
\hline NET BALANCE & $-5,000$ & -570 & $+4,283,44$ & $+7,529.94$ & $+8,560.27$ \\
\hline
\end{tabular}

Investment project II is also absolutely profitable, because its compound value $(\$ 8,560.27)$ exceeds the opportunity income value $\left(\$ 5,000 \square 1.09^{4}=\$ 7,057.91\right)$.

To assess relative profitability, we must determine the extent to which the projects are comparable, given their differences in investment outlay and economic life, and if necessary, how comparability can be achieved. The VoFI method explicitly considers the manner in which the initial investment outlay is financed. Therefore, different initial investment outlays impair project comparability only if one (or more) of the mutually exclusive projects has an initial outlay less than the allocated equity capital. In that case, (not shown in the example), an assumption about a supplementary investment is needed to balance the difference in the allocated equity. For example, we can assume that the excess amount is invested to yield the opportunity interest rate.

Economic life differences must be balanced in every case; otherwise compound values referring to different periods will not be comparable. The capital available at the end of the shorter investment project has to be compounded by an appropriate interest rate to balance the life differences. In the example given, the compound value of project I has to be compounded by a further year before it can be compared with the compound value of project II. Assuming an interest rate of $9 \%$, the compound value of $I$ is $\$ 8,207.63$ at the end of $t=4(\$ 7,529.94 \square 1.09)$. Because 
the compound value of the project II $(\$ 8,560.27)$ is higher, II is relatively profitable. Other investment appraisal methods may provide differing results. As shown in the appendix the net present value method and the internal rate of return method indicate the same absolute and relative profitabilities, while the compound value method and the critical debtor interest rate method show project I to be the relatively profitable.

The company's VoFI capital profitabilities can be derived by:

$$
\begin{aligned}
& 4 \sqrt{-} \frac{8.207}{5,000}-1=13.19 \% \\
& 4 \sqrt{-} \frac{8.560}{5,000}-1=14.39 \%
\end{aligned}
$$

Both projects are absolutely profitable, because their interest rates exceed the opportunity interest rate. Project II emerges as relatively profitable due to its higher company VoFI capital profitability.

\section{ASSESSMENT OF THE VOFI METHOD AND SUMMARY}

The VoFI method is a relatively simple method for assessing alternative investment projects. Data required are the cash flow profiles of the investment projects; the amounts of available equity capital that can be assigned to the investment project; debt capital components under all relevant financial conditions (redemption types, interest rates etc.); the opportunity income interest rate; and the credit interest rate for short-term investments. Some of these data can determined independent of the chosen investment appraisal method and are therefore available in each case. Other data would have to be obtained especially for using the VoFI method; it has to be considered whether this is possible but some may be obtained with justifiable efforts.

A main problem is caused by the fact that financing and investment policies are usually not tailored to individual projects, but rather to the whole company. In this case, the allocation of equity and specific loans to individual projects will be difficult. However, this problem does not occur with, for example, strategically important investments (e.g. foundational investments for new plant or business locations, and foreign investments) or with certain projects such as real-estate purchases, which require their own financial design. Additionally, it should be noted that future current account and debt interest rates are generally uncertain.

The assumptions of the VoFI method are largely those of the NPV method: (a) only one target measure is pursued (although other target measures may be employed), (b) a given economic life is assumed, (c) other decisions are not explicitly considered and, thus, the investment decisions do not affect them and cash flows are attributable to different periods, and to specific projects, and (d) the data is assumed to be certain.

In this connection it shall be pointed out that the VoFI method can also be used for the determination of the optimum economic lives and the replacement times and that uncertainty can be included in VoFI models as well. However, compared to NPV the VoFI method is better suited to the determination of optimum economic life and replacement times and can cope better with uncertainty. For instance, a payback period can be determined when the existing total balance equals the compounded opportunity income value. In the examples given, it was assumed that all payments take place at the end of a period (year). This assumption can be easily changed, by adjusting the VoFI analysis to a monthly (or other) time frame.

Independent decisions in other company areas are only partially considered in relation to financial decisions, because at the beginning of the second and following periods decisions may be needed about the extent of debt use (or repayment) that results from net cash outflows or inflows.

Moreover, in an extension to the examples presented here, the optimum financing of individual investment projects can be determined. This is motivated by the fact, that in an imperfect capital market, the optimum investment and financing decisions are not independent from each other (i.e. the FISHER Separation Theorem does not apply). The way in which investment projects are financed, therefore, are relevant to the assessment of those projects. In the 
case of decisions about a single investment project, the aim is to identify the optimum financing possibility and use this as a basis for the project appraisal. Therefore in addition, a compound value can be calculated for every combination of investment and financing using the VOFI comprehensive financial plan. The combination with the maximum compound value represents the optimum. Alternatively, optimization models for simultaneous equations, which include financing possibilities as variables, can be used to determine the optimum financing for each project. In the same way, it can be determined whether any financial surpluses should be used to pay back loans. However, the VoFI approach does not consider all interdependencies between different investment projects and financial investments.

In contrast to the NPV method, the VoFI method does not assume that cash flow are reinvested at a uniform discount rate, nor does it require investments to balance differences in capital tie-up and/or economic life. The shortterm investment of cash flow surpluses is assumed to earn the credit interest rate. Capital tie-up differences are limited to the equity capital available at the beginning of the planning period, and can be balanced individually. The same applies to economic life differences (with the determination of the relevant interest rate being particularly problematical).

In summary, the VoFI method requires simplifying assumptions about financing and investment opportunities in order to avoid the planning scenario becoming too complicated. An advantage of the VoFI method over other investment appraisal methods is that assumptions about the reinvestment of surpluses and the comparison of profitabilities are transparent within the standardized tables. Also, the draft comprehensive financial plans can be modified in regard to further assumptions, enhancing the transparency of this approach compared to other appraisal methods. Overall, VoFI analysis results are well suited to clear presentation and control, so they are likely to be highly acceptable to decision makers.

A major difference between the VoFI and NPV methods concerns the assumptions about the capital market. While the NPV method assumes a perfect capital market, as shown, the VoFI method can include not only differences between credit and debt interest rates, but also the capacity for self-financing and a huge variety of loan conditions and equity interest rates, especially short term investment opportunities. This is a second reason for preferring the VoFI method. In an imperfect capital market, investment and consumption decisions are not separable, but under the VoFI method consumption can be considered in a simplified form by maximizing the cash withdrawals attainable to the project.

Moreover, where capital markets are imperfect, certainty usually assumed in investment appraisal methods, cannot exist. In reality, investing companies do face an imperfect capital market and uncertainty, so to assume otherwise is an oversimplification. However, the arguments presented here reflect the view of the author that these simplifying assumptions can be appropriate in some situations. In other cases, the models presented here are a first step towards dealing with uncertainty and imperfect capital markets within the investment appraisal process.

\section{REFERENCES}

1. ANOn. (2006): A Pragmatic Approach to Management Accounting Research, in: Management Accounting Research, Vol. 29, Issue 6, o, 358-371.

2. BIERMAn, H.; SMIDT, S. (2002): The Capital Budgeting Decision, Upper Saddle River: Prentice Hall.

3. Bоотн, R. (1999): Avoiding Pitfalls in Investment Appraisal, in: Management Accounting, Vol. 77, No. 10, pp. 22-23.

4. DAYANANDA, D. ET AL. (2002): Capital Budgeting. Financial Appraisal of Investment Projects, Cambridge: Cambridge University Press.

5. DRURY, C.; TAYLES, M. (1997): The Misapplication of Capital Investment Appraisal Techniques, in: Management Decisions, Vol. 35, No. 1-2, p. 86-93.

6. GROB, H. L. (1993): Capital Budgeting with Financial Plans, Gabler: Wiesbaden.

7. GÖTZE, U.; NORTHCOTT, D.; SCHUSTER, P. (2007): Investment Appraisal. Methods and Models, SpringerVerlag: New York et al. (with a number of further references). 
Prof. Dr. Peter Schuster is professor of Management Accounting and Management Control at Schmalkalden University of Applied Sciences in Schmalkalden, Germany.

\section{APPENDIX}

Solution of the example using other investment appraisal methods:

Most popular investment appraisal methods require further assumptions/ information; e.g. the Net Present Value Method a uniform discount rate. In doing so and selecting a rate of $10 \%$, the assessment using this method leads to the following results: $\mathrm{NPV}_{\mathrm{I}}=+\$ 931.63, \mathrm{NPV}_{\mathrm{II}}=+\$ 1,136.40$; e.g. both projects are absolutely profitable and project II is relatively profitable.

The assessment using the internal rates of return method leads to the following results: $\mathrm{r}_{\mathrm{I}}$ : (ca.) $15.66 \%$ and $\mathrm{r}_{\text {II }}$ (ca.) $13.86 \%$; now, project I is the relatively profitable.

The use of the internal rate of return method for determining the relative profitability is questionable due to the problem of the reinvestment assumption (e.g., it is assumed that cash flow surpluses can be reinvested anytime at the IRR (r). If this represents the perfect capital market interest level, the investment project would not be absolutely profitable, as only an NPV=0 would be achievable!

Assuming now a debt rate of interest of $\mathrm{d}=12 \%$ and a credit rate of interest of $\mathrm{c}=8 \%$ the assessment are repeated using the compound value method under the assumption of

- $\quad$ mandatory accounts balancing (surpluses are used for immediate redemption) and then

- $\quad$ prohibited accounts balancing (surpluses are not used for capital redemption until the end of the economic life).

The results are compound values of the investment projects (at $\mathrm{t}=4$ ) under the assumption a) are:

- $\quad$ investment project I: $+\$ 888.54$

- $\quad$ investment project II: $+\$ 830.15$ (I is relatively profitable)

The results are compound values of the investment projects (at $t=4$ ) under the assumption $b$ ) are:

- $\quad$ investment project I: $+\$ 197.34(+\$ 182.72$ at $\mathrm{t}=3)$

- $\quad$ investment project II: $-\$ 117.49$ (I is relatively profitable)

The Assessment is repeated with the critical debtor interest rate method in turn respecting the assumptions of

- $\quad$ mandatory accounts balancing, and then

- prohibited accounts balancing.

The results are critical debtor interest rates of the investment projects (at $t=4)$ under the assumption a) are:

- $\quad$ investment project I: $15.66 \%$

- $\quad$ investment project II: $13.86 \%$ (I is relatively profitable)

The results are critical debtor interest rates of the investment projects (at $t=4$ ) under the assumption $b$ ) are:

- $\quad$ investment project I: $12.48 \%$

- $\quad$ investment project II: $11.83 \%$ (I is relatively profitable).

For detailed instruction about the calculation see: GÖTZE, NORTHCOTT, SCHUSTER 2007. 
International Business \& Economics Research Journal - September 2007

Volume 6, Number 9

\section{NOTES}

